\title{
THE EEFECT OF READING HABITS AND VOCABULARY MASTERY ON READING SKILL OF ENGLISH TEXT PROCEDURES
}

\author{
William March Hatimurah ${ }^{1}$ \\ Universitas Indraprasta PGRI \\ e-mail: williammarch1995@gmail.com ${ }^{1}$
}

\begin{abstract}
Abstrak: Tujuan dari penelitian ini adalah untuk mengetahui: 1) Pengaruh kebiasaan membaca dan penguasaan kosakata secara bersama-sama terhadap kemampuan membaca teks prosedur bahasa Inggris. 2) Pengaruh kebiasaan membaca terhadap kemampuan membaca teks prosedur bahasa Inggris. 3) Pengaruh penguasaan kosakata terhadap kemampuan membaca teks prosedur bahasa Inggris. Metode dalam penelitian ini adalah survei. Populasi dalam penelitian ini adalah siswa kelas VIII SMP Swasta di Jakarta Timur dengan besar sampel sebanyak 90 siswa yang diambil secara acak dari siswa SMP Widya Manggala Jakarta Timur dan siswa SMP Kuntum Wijaya Kusuma Jakarta Timur. Penelitian dilaksanakan pada bulan September-November 2019. Instrumen yang digunakan adalah angket kebiasaan membaca, nilai tes penguasaan kosakata dan nilai tes kemampuam membaca teks prosedur bahasa Inggris. Analisis dilakukan dengan metode regresi linear ganda. Hasil pengujian hipotesis diperoleh kesimpulan sebagai berikut: 1) Terdapat pengaruh yang signifikan kebiasaan membaca dan penguasaan kosakata secara bersama-sama terhadap kemampuan membaca teks prosedur bahasa Inggris siswa SMP Swasta di Jakarta Timur. Hal ini dibuktikan dengan perolehan nilai $\mathbf{S i g}=0,000<0,05$ dan $\mathbf{F}_{\text {hitung }}=$ 6,885. 2) Terdapat pengaruh yang signifikan kebiasaan membaca terhadap kemampuan membaca teks prosedur bahasa Inggris siswa SMP Swasta di Jakarta Timur. Hal ini dibuktikan dengan perolehan nilai Sig $=0,001<0,05$ dan $t_{\text {hitung }}=3,412$. 3) Terdapat pengaruh yang signifikan penguasaan kosakata terhadap kemampuan membaca teks prosedur bahasa Inggris siswa SMP Swasta di Jakarta Timur. Hal ini dapat dibuktikan dengan perolehan nilai Sig = 0,042 $<0,05$ dan $t_{\text {hitung }}=2,062$. Berdasarkan pada hasil penelitian di atas, bahwa kebiasaan membaca dan penguasaan kosakata memberikan pengaruh yang berarti terhadap kemampuan membaca teks prosedur bahasa Inggris siswa.
\end{abstract}

Kata Kunci: membaca, kosakata, membaca teks prosedur bahasa Inggris

\section{Pendahuluan}

Saat ini kebutuhan manusia akan pengetahuan terus meningkat seiring perkembangan zaman. Manusia melakukan berbagai usaha untuk meningkatkan ilmu pengetahuan mereka dengan berbagai cara salah satunya yakni dengan belajar. Saat ini belajar merupakan kebutuhan mendasar yang sangat diperlukan oleh setiap manusia, tanpa belajar manusia tidak dapat berkembang dan menciptakan inovasi-inovasi yang baru. Belajar merupakan proses perubahan tingkah laku dan pola pikir manusia dari tidak tahu menjadi tahu. Dengan belajar manusia dapat menjadikan diri mereka lebih bermanfaat serta mampu terjun ke masyarakat sehingga terciptalah masyarakat pembelajar yang siap menghadapi perkembangan zaman.

Dengan terciptanya masyarakat pembelajar ini maka terbentuk pula manusia-Manusia yang tidak pernah puas untuk terus belajar. Masyarakat pembelajar menjadikan proses belajar itu sebagai suatu kebutuhan yang mutlak harus dipenuhi dalam kehidupan, masyarakat pembelajar juga selalu haus akan ilmu pengetahuan. pendidikan merupakan jembatan penghubung untuk menciptakan generasi pembelajar yang memiliki tingkat intelektual yang tinggi. Dengan belajar terus-menerus masyarakat 
mampu merubah dan memperbaiki taraf hidup mereka karena adanya pengetahuan dan pola pikir yang maju yang diperoleh dari pendidikan.

Masyarakat pembelajar menggunakan berbagai kesempatan untuk memperoleh ilmu pengetahuan, bahkan mereka belajar dari pengalaman-pengalaman hidup mereka dan dari semua aspek yang ada seperti: majalah, Koran, televisi, novel, internet, artikel, politik, sosial budaya, ekonomi serta agama.

Masyarakat pembelajar menjadikan belajar sebagai bagian dari kebutuhan hidupnya yang harus dipenuhi. Melalui kegiatan yang direncanakan secara matang dan dengan tujuan yang jelas, pendidikan mampu menciptakan para siswanya menjadi manusia pembelajar kelak di masyarakat.pendidikan dapat memunculkan lebih banyak lagi para pemimpin dan akademisi yang hidupnya banyak bermanfaat bagi umat manusia. Semakin banyak jumlah manusia pembelajar di Indonesia, maka semakin banyak pula sumber pemecahan masalah kehidupan bermasyarakat, berbangsa dan bernegara.

Pendidikan merupakan suatu upaya atau usaha kegiatan yang bertujuan, pendidikan dapat diperoleh dari suatu kegiatan yang terstruktur dan disusun secara detil maupun tidak. Dengan kata lain bahwa pendidikan itu tidak hanya diperoleh di sekolah melalui cara-cara yang telah ditetapkan, melainkan dapat diperoleh di luar sekolah dan memiliki tujuan yang sama yakni untuk membentuk pola pikir dan ilmu pengetahuan masyarakat.

Adapun salah satu perwujudan pelaksanaan pendidikan itu adalah pembelajaran bahasa Inggris. Bahasa Inggris merupakan salah satu Bahasa yang paling mendunia saat ini dan sampai masa yang akan datang, bukan dari tingkat kesulitannya tetapi bahasa Inggrislah yang merupakan bahasa yang telah disepakati pemerintah dunia sebagai bahasa yang digunakan untuk berbicara dan berkomunikasi dengan semua orang. Oleh karena itu, semua jenjang pendidikan mulai dari tingkat terendah sampai kepada tingkat tertinggi, tidak luput dari pendidikan bahasa Inggris.

Saat sekarang ini banyak pandangan yang mengatakan bahwa pembelajaran bahasa Inggris kurang efektif karena siswa pada umumnya masih terfokus pada pengajaran tata bahasa tanpa adanya penekanan terhadap kebiasaan untuk membaca serta memperoleh kosakata bahasa Inggris yang lebih banyak sehingga itulah yang menjadikan siswa tidak mengalami progres dalam pembelajaran berbahasa Inggris.

Pembelajaran bahasa dilakukan untuk mengetahui seberapa dalam bahasa itu memberikan efek yang positif dalam diri seseorang sehingga membentuk perilaku, pembelajaran bahasa Inggris itu memiliki suatu orientasi yang kuat yang pada hakikatnya harus bisa dimiliki oleh setiap orang yakni dengan memiliki tekat yang kuat pula serta kebiasaan untuk terus belajar agar tujuan pembelajaran dapat tercapai secara maksimal. Agar siswa dapat lebih baik lagi dalam proses belajar bahasa Inggris, maka mereka harus dibekali dengan berbagai keterampilan dalam berbahasa Inggris untuk menunjang proses belajar mereka supaya lebih efektif dengan kegiatan menyimak, berbicara, menulis serta membaca.

Kegiatan membaca sangat penting dalam proses belajar bahasa Inggris. Dengan kebiasaan membaca, siswa mampu mengolah setiap kosakata dalam pikiran mereka serta dapat meningkatkan kemampuan mereka dalam membaca teks berbahasa Inggris. Dengan bekal inilah, siswa bisa memperluas serta menambah wawasan mereka melalui informasi yang mereka dapatkan dari kebiasaan mereka membaca teks dalam bahasa Inggris.

\section{Pengertian Kebiasaan}

Kebiasaan merupakan suatu perilaku abstrak yang dilakukan berulang-ulang kali baik itu disadari maupun yang tidak disadari oleh manusia itu sendiri. Seringkali kebiasaan menjadi tolak ukur manusia dalam menentukan seberapa jauh pengetahuan dan seberapa baik atau buruknya perilaku seseorang akan suatu hal. Makan dengan menggunakan tangan kanan, memberikan segala sesuatu kepada orang lain dengan menggunakan tangan kanan, tidur mendengkur merupakan kebiasaan umum yang sering dilakukan oleh seseorang.

Setiap manusia memiliki kebiasaan yang berbeda-beda, berangkat dari suatu tingkah laku yang dikerjakan satu dua kali bahkan berulang kali yang menjadi suatu kebiasaan. Kebiasaan yang dilakukan 


\section{INFERENCE: Journal of English Language Teaching}

Vol. 3, No. 1, April - July 2020

p-ISSN: 2615-8671

e-ISSN: 2615-868X

secara terus menerus dalam jangka waktu yang sangat lama dapat membentuk kepribadian seseorang dan pada akhirnya menjadi watak atau ciri khas seseorang tergantung kemana arah kebiasaan itu mulai terbentuk, apakah ke arah kebiasaan yang baik atau buruk. Dengan kata lain kebiasaan merupakan suatu kegiatan berulang yang sejak lama dilakukan sehingga terjadi begitu saja secara otomatis dan tanpa melalui proses berpikir panjang dan terkadang itu terjadi tanpa disadari. Semakin lama kebiasaan itu timbul dalam diri seseorang maka itu akan menjadi suatu kepribadian di dalam diri orang tersebut. Dalam hal ini pula, lingkungan sangatlah berperan aktif dalam membentuk kebiasaan di dalam diri seseorang, lingkungan yang baik akan membentuk kebiasaan yang baik sedangkan lingkungan yang buruk akan membentuk kebiasaan yang buruk, tergantung dimana orang tersebut tinggal dan bagaimana respon dalam menyikapi hal-hal yang dapat mempengaruhi kepribadiannya dikemudian hari.

Gardner (2012:32) mengemukakan mengenai kebiasaan bahwa "Habit is often used to refer to an action done frequently" yang berarti bahwa kebiasaan itu dilakukan pada saat melakukan kegiatan atau hal yang sama dalam jumlah yang tidak ditentukan, dengan kata lain bahwa selama kegiatan yang sama itu muncul maka disitu pula akan timbul respon atau tindakan yang sama pula yang nantinya akan menyebabkan yang namanya kebiasaan. Perbuatan seseorang dapat dikatakan sebagai suatu kebiasaan apabila menjadi perilaku sehari-hari.

Kebiasaan itu mengalir dengan sendirinya dalam pikiran manusia dan diwujudkan melalui tingkah laku yang sama, yang telah dilakukan secara berulang dalam kehidupan. Tidak ada Satu pun manusia yang hidup di dunia ini tanpa suatu kebiasaan. Setiap manusia memiliki kebiasaan yang unik tergantung kepribadian masing-masing. Kebiasaan seseorang dapat diubah tergantung dari keinginan serta tekat yang kuat yang muncul di dalam diri seseorang baik itu kebiasaan yang baik ataupun kebiasaan yang buruk. Kebiasaan yang baik dapat berubah menjadi suatu kebiasaan yang buruk begitu pun sebaliknya. Oleh karena itu dari beberapa teori dan opini di atas mengenai kebiasaan maka dapat ditarik kesimpulan bahwa kebiasaan merupakan suatu perilaku berulang yang terjadi secara otomatis tanpa harus berpikir panjang.

\section{Pengertian Kebiasaan Membaca}

Kebiasaan membaca menjadi salah satu bagian dalam kehidupan manusia dan dalam kehidupan bermasyarakat. Pada zaman sekarang ini manusia akan terus-terusan disuguhkan oleh berbagai macam teks bacaan untuk dibaca oleh karena ketersediaan sarana dan prasarana penunjang serta teknologi informasi dan komunikasi yang semakin modern, mulai dari membaca pesan singkat pada perangkat telepon genggam, jejaring sosial sampai pada buku-buku elektronik.

Dari hal inilah maka akan dengan sendirinya tercipta suatu kebiasaan di dalam diri setiap manusia untuk membaca. Kebiasaan membaca tidak akan pernah terlepas dari kehidupan manusia seiring perkembangan zaman. Chettri \& Rout (2013:13) mengemukakan bahwa "Reading habit is a reading activity which done recursively". Perlu diperhatikan bahwa kebiasaan membaca ini harus terus-menerus dilakukan sehingga diperoleh suatu ilmu pengetahuan yang tidak terbatas. Dengan kebiasaan membaca maka kemampuan seseorang juga akan terus meningkat, mulai dari kemampuan untuk berpikir kritis, banyaknya kosakata yang dimiliki sampai kemampuan untuk memahami makna bacaan.

Kebiasaan membaca adalah bukti nyata yang dapat dilihat oleh semua orang. Dengan melakukan kebiasaan membaca, seseorang dapat memberikan contoh kepada orang lain bahwa membaca itu sangat penting dalam kehidupan ini. Banyak wawasan serta ilmu pengetahuan yang dapat kita peroleh dari kebiasaan membaca. Seseorang dapat mengontrol perilaku mereka dan menyesuaikannya dengan keadaan sekitar karena orang yang memiliki kebiasaan membaca mempunyai pola pikir yang baik dan cara untuk mengatasi masalah. Tingkat kecerdasan serta intelektual seseorang akan terus meningkat dengan cara memberi respon yang baik terhadap kebiasaan membaca. Apabila kebiasaan membaca ditekuni dengan baik maka seseorang tidak akan henti-hentinya memiliki perasaan ingin tahu. Seseorang yang sudah memiliki kebiasaan seperti ini tidak akan mudah bosan dengan apa yang ia lakukan, malah mereka akan menghabiskan waktu mereka untuk membaca karena kebiasaan membaca sudah sangat melekat dalam diri mereka.

Kebiasaan membaca merupakan sikap atau prilaku yang mengekspresikan rasa suka dan gemar terhadap kegiatan membaca dan juga ragam bacaan. Orang yang gemar membaca pasti senang dan memiliki rasa penasaran yang tinggi terhadap berbagai macam bacaan. Mereka akan cenderung mencari 
teks atau buku-buku lain untuk dijadikan sebagai bahan bacaan baik itu dari berbagai sumber bahkan dari berbagai cabang ilmu pengetahuan. Jadi dari beberapa pendapat dan teori yang telah dijelaskan di atas maka dapat disimpulkan bahwa kebiasaan membaca itu adalah aktivitas membaca yang tidak dibatasi waktu dan yang sudah membudaya dalam diri seseorang.

\section{Pengertian Penguasaan Kosakata}

Menguasai kosakata itu tidak semudah seseorang membalikkan telapak tangan, butuh usaha dan kerja keras untuk memperoleh hasil yang ingin dicapai. Sangatlah sering dijumpai banyaknya orang atau pelajar yang tidak dapat berbicara, memahami isi bacaan dan menulis dalam bahasa Inggris disebabkan karena mereka kurang perbendaharaan atau bahkan tidak tahu kosakata apa yang mereka harus ucapkan dan gunakan. Hal ini pula yang membuat mereka tidak dapat menyimak dengan baik apa yang disampaikan atau dikatakan oleh penutur asli maupun penutur lain yang menggunakan bahasa Inggris bahkan oleh guru-nya sekalipun yang menyampaikan informasi, petun-juk atau pelajaran.

Penguasaan kosakata harus berlandaskan atas keinginan serta motivasi seseorang untuk menguasai suatu bahasa. Dengan belajar terus-menerus dan membiasakan diri mengucapkan kosakata maka seseorang akan mudah menguasainya tanpa harus berlama-lama memikirkan apa yang harus diucapkan karena banyaknya kosakata yang telah diketahui.

Penguasaan kosakata ditunjukkan melalui kemahiran seseorang dalam menggunkan setiap kata dengan baik dan lancer dalam berkomunikasi dan juga berinteraksi, itulah yang disebut dengan penguasaan kosakata. Setiap orang yang sudah tidak canggung dan tidak terbata-bata dalam berbahasa berarti orang tersebut sudah menguasai setiap kosakata dalam bahasa itu. Maka dari itu sama halnya dalam penguasaan kosakata bahasa Inggris, seseorang harus bisa menggunakan kemampuannya sebaik mungkin agar lancer dalam berkomunikasi dengan banyak belajar tentang kosakata bahasa Inggris.

Pendapat lain muncul dari Fletcher (2005:124) yang mengemukakan bahwa "Vocabulary mastery or semantic competence is also multi-faced, with the possibility that only some aspects are sensitive to the timing of first language acquisition". Maksudnya bahwa penguasaan kosakata merupakan suatu hal yang sensitif dalam hal penguasaan bahasa, ini sudah menjadi suatu aturan dalam hal berbahasa. Tanpa penguasaan kosakata akan sulit untuk menguasai suatu bahasa, begitu pula dengan pembelajaran bahasa Inggris, penguasaan kosakata bahasa Inggris menjadi hal yang paling mendasar dalam pembelajaran yang efektif.

Wilkins (dalam Harmer 2002:24) yang mengemukakan bahwa "Without grammar very little can be conveyed, without vocabulary nothing can be conveyed". Dengan ini Walkins menjelaskan bahwa, penguasaan kosakata sebagai salah satu komponen bahasa yang akan mendukung kemampuan siswa dalam berkomunikasi baik lisan maupun tulisan. Penguasaan kosakata merupakan satu bagian inti dari bahasa dalam hal kemahiran dan menentukan seberapa baik peserta didik berbicara, mendengarkan, membaca, dan menulis. Jadi, dari beberapa teori serta opini di atas, dapat ditarik kesimpulan bahwa penguasaan kosakata adalah kemahiran seseorang dalam menggunakan kosakata.

\section{Pengertian Teks Prosedur}

Teks prosedur merupakan teks yang paling banyak berhubungan dengan kehidupan. Apapun pekerjaan seseorang selalu berhubungan dengan teks proses melakukan sesuatu. Mulai pagi hingga malam hari seseorang selalu membaca teks prosedur dalam bentuk melakukan kegiatan. Pada saat bangun tidur, seseorang membaca teks prosedur dalam bentuk kegiatan mandi, menyapu, memasak nasi, membuat minuman, makanan dan lain sebagainya. Seorang guru atau dosen pun selalu menjumpai teks prosedur dalam melaksanakan pekerjaannya, seperti bagaimana membuat program pembelajaran, bagaimana mengajar yang baik, bagaimana membuat soal latihan yang baik dan bagaimana cara menilai yang baik. Teks prosedur merupakan teks yang sangat penting dipelajari karena teks prosedur ini selalu berhubungan dengan kehidupan seseorang, apapun profesi seseorang, selalu berhubungan dengan teks prosedur.

Teks prosedur merupakan suatu teks yang berisikan tahap-tahan untuk melakukan sesuatu. Teks tersebut menjadi suatu panduan bagi para pembaca untuk dapat menyelesaikan suatu kegiatan dengan baik dengan mengikuti petunjuk yang ada pada teks tersebut. Teks prosedur merupakan suatu teks yang memberikan petunjuk yang benar dan lengkap kepada seseorang tentang bagaimana mengerjakan 


\section{INFERENCE: Journal of English Language Teaching}

Vol. 3, No. 1, April - July 2020

p-ISSN: 2615-8671

e-ISSN: 2615-868X

sesuatu dengan cepat sesuai dengan apa yang telah disampaikan dalam isi teks tersebut, dengan mengikuti beberapa langkah dan juga tindakan serta penanganan yang tepat. Dari penjelasan beberapa teori dan juga opini mengenai teks prosedur maka dapat disimpulkan bahwa teks prosedur adalah teks yang menjelaskan bagaimana cara melakukan, membuat dan memproses sesuatu.

Dari uraian di atas dapat disimpulkan bahwa, jika siswa semakin membiasakan diri mereka untuk membaca teks prosedur, maka kemampuan mereka untuk menguasai berbagai teks prosedur dan segala aspeknya, serta penguasaan kosakata siswa akan semakin baik. Apabila siswa sudah terbiasa dengan membaca teks prosedur bahasa Inggris maka siswa juga sudah mampu mengungkapkan berbagai informasi yang terkandung di dalamnya dengan sangat mudah. Untuk itu peneliti ingin mengetahui masalah yang terkait dengan kebiasaan membaca dan penguasaan kosakata, maka peneliti mengadakan penelitian dengan judul: "Pengaruh Kebiasaan Membaca dan Penguasaan Kosakata Terhadap Kemampuan Membaca Teks Prosedur Bahasa Inggris pada SMP Swasta di Jakarta Timur".

\section{Metode}

Metode yang digunakan dalam penelitian ini adalah survey dengan teknik korelasional. Variable penelitian ini terdiri dari variable terikat, yaitu kemampuan memaca teks prosedur ( $\mathrm{Y}$ ) dan dua variable bebas $(\mathrm{X})$, yaitu kebiasaan membaca $\left(\mathrm{X}_{1}\right)$ dan penguasaan kosakata $\left(\mathrm{X}_{2}\right)$, maka model konstelasi hubungan antar variable dalam penelitian ini ada sebagai berikut:

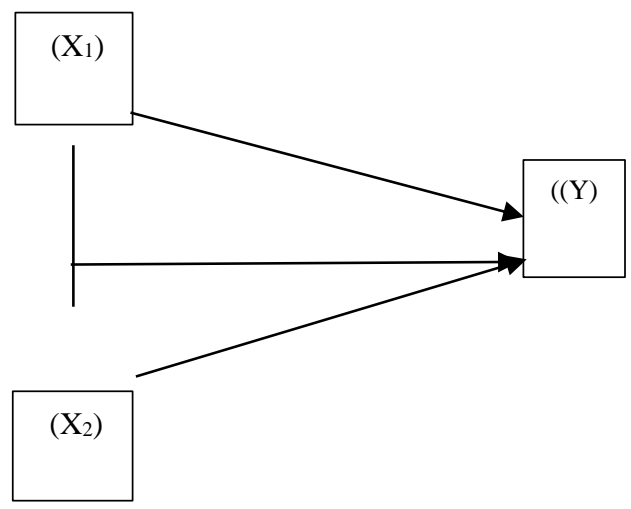

Gambar 1. Konstelasi Hubungan antar Variabel Penelitian

Keterangan:

$\left(\mathrm{X}_{1}\right) \quad$ : Kebiasaan Membaca

$\left(\mathrm{X}_{2}\right) \quad$ : Penguasaan Kosakata

(Y) : Kemampuan Membaca Teks Prosedur

1. Pengaruh Kebiasaan Membaca dan Penguasaan Kosakata terhadap Kemampuan Membaca Teks Prosedur Bahasa Inggris.

2. Pengaruh Kebiasaan Membaca terhadap Kemampuan Membaca Teks Prosedur Bahasa Inggris. Survei pada penelitain ini menggunakan analisis regresi linear berganda, yaitu untuk mencari:

1. Pengaruh kebiasaan membaca dan penguasaan kosakata secara bersama-sama terhadap kemampuan membaca teks prosedur bahasa Inggris.

2. Pengaruh kebiasaan membaca terhadap kemampuan membaca teks prosedur bahasa Inggris.

3. Pengaruh penguasaan kosakata terhadap kemampuan membaca teks prosedur bahasa Inggris. 


\section{Hasil dan Diskusi}

\section{Deskripsi Data}

1. Data kemampuan membaca teks prosedur Bahasa Inggris $(Y)$

Data kemampuan membaca teks prosedur bahasa Inggris diperoleh dari nilai tes sebanyak 90 siswa yang menjadi sampel penelitian. Nilai yang di peroleh adalah terendah 13, tertinggi 39 , rata-rata sebesar 22,01 median sebesar 21,00, modus sebesar 21 dan simpangan baku sebesar 5,647.

Tabel 1.Deskripsi Data Penelitian Prestasi Belajar Bahasa Inggris

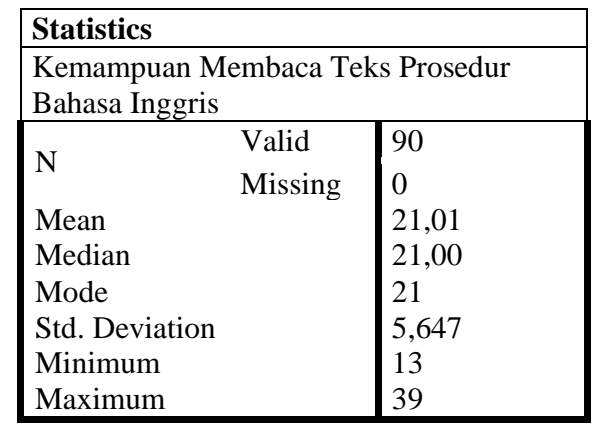

Bila dilihat dari hasil perhitungan di atas, maka bisa dikatakan bahwa kemampuan membaca teks prosedur bahasa Inggris siswa SMP Swasta di Jakarta Timur bersifat homogen. Hal ini diindikasikan dengan perolehan nilai rata-rata sebesar 21,01. Untuk memperjelas data di atas, digambarkan dalam histogram sebagai berikut:

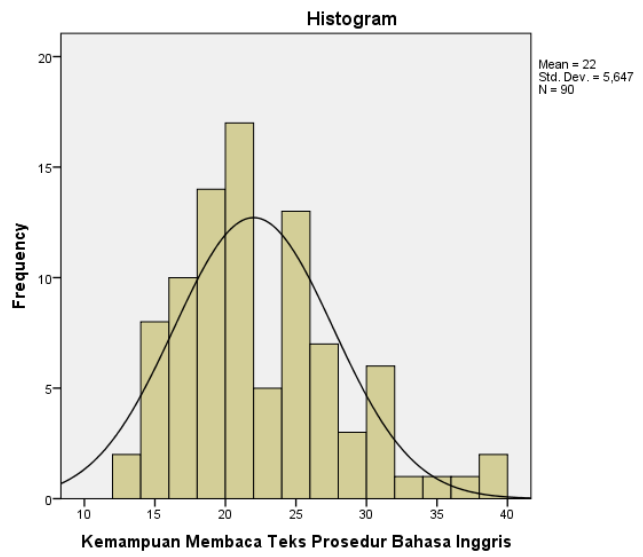

Gambar 2. Histogram Poligon Variabel Kemampuan Membaca Teks Prosedur Bahasa Inggris

Dari histogram dan poligon frekuensi di atas dapat disimpulkan bahwa data kemampuan membaca teks prosedur Inggris siswa SMP Swasta di Jakarta Timur memiliki distribusi normal.

\section{Data Kebiasaan Membaca (X1)}

Data kebiasaan membaca diperoleh dari kuesioner yang dijawab oleh 90 siswa sebagai responden dihasilkan nilai terendah 10 , skor tertinggi 28 , skor rata-rata sebesar 18,81 , median sebesar 18,50, modus sebesar 18 dan simpangan baku sebesar 4,085. 
INFERENCE: Journal of English Language Teaching

Vol. 3, No. 1, April - July 2020

p-ISSN: 2615-8671

e-ISSN: 2615-868X

Tabel 2. Deskripsi data Penelitian Minat Baca

\begin{tabular}{|c|c|c|}
\hline \multicolumn{3}{|c|}{ Statistics } \\
\hline \multicolumn{3}{|c|}{ Kebiasaan Membaca } \\
\hline \multirow[b]{2}{*}{$\mathrm{N}$} & Valid & 90 \\
\hline & Missing & 0 \\
\hline \multicolumn{2}{|c|}{ Mean } & 18,81 \\
\hline \multicolumn{2}{|c|}{ Median } & 18,50 \\
\hline \multicolumn{2}{|c|}{ Mode } & 18 \\
\hline \multicolumn{2}{|c|}{ Std. Deviation } & 4,085 \\
\hline \multicolumn{2}{|c|}{ Minimum } & 10 \\
\hline \multicolumn{2}{|c|}{ Maximum } & 28 \\
\hline
\end{tabular}

Dari hasil perhitungan di atas, maka bisa dikatakan bahwa kebiasaan membaca siswa SMP Swasta di Jakarta Timur bersifat homogen. Hal ini diindikasikan dengan perolehan nilai rata-rata skor 18,81 mendekati skor mediannya. Untuk memperjelas data di atas, digambarkan dalam histogram sebagai berikut:

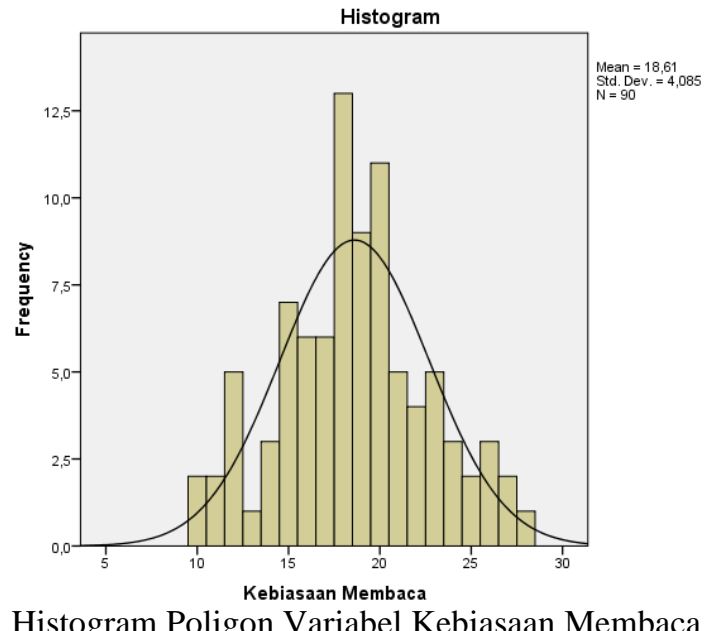

Gambar 3. Histogram Poligon Variabel Kebiasaan Membaca

Dari histogram dan poligon frekuensi di atas dapat disimpulkan bahwa kebiasaan membaca siswa SMP Swasta di Jakarta Timur memiliki sebaran yang normal.

3. Data Penguasaan Kosakata (X2)

Data penguasaan kosakata diperoleh dari hasil angket yang di jawab oleh 90 siswa dihasilkan skor terendah 9 , skor tertinggi 24 , skor rata-rata sebesar 16,88, median 17,50, modus sebesar 18, dan simpangan baku sebesar 3,489.

Tabel 3. Deskripsi data Penelitian Penguasaan Kosakata

\begin{tabular}{|l|l|}
\hline \multicolumn{2}{|l|}{ Statistics } \\
\hline \multicolumn{2}{|l|}{ Penguasaan Kosakata } \\
\hline $\mathrm{N} \quad$ Valid & 90 \\
Mean Missing & 0 \\
Median & 16,88 \\
Mode & 17,50 \\
Std. Deviation & 18 \\
Minimum & 3,647 \\
Maximum & 9 \\
\hline a. Multiple modes exist. The \\
smallest value is shown \\
\hline
\end{tabular}


Dari hasil perhitungan di atas, maka dapat dikatakan bahwa data penguasaan kosakata siswa SMP Swasta di Jakarta Timur bersifat homogen. Hal ini diindikasikan dengan perolehan skor rata-rata sebesar 16,88 mendekati nilai mediannya. Untuk memperjelas data di atas, digambarkan dalam histogram sebagai berikut :

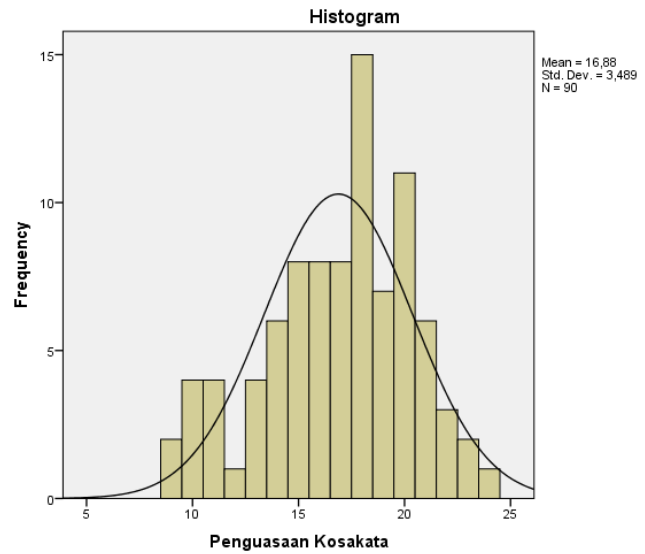

Gambar 4. Histogram Poligon Variabel Penguasaan Kosakata

Dari histogram dan poligon frekuensi di atas dapat disimpulkan bahwa data penguasaan kosakata siswa SMP Swasta di Jakarta Timur memiliki sebaran yang normal.

\section{A. Uji Persyaratan Analisis Regresi}

1. Uji Asumsi Klasik

a. Uji Normalitas Data

Persyaratan regresi yang baik jika data penelitian mengikuti distribusi normal.

Tabel 5. Uji Normalitas Data

\begin{tabular}{|c|c|c|c|c|}
\hline & & $\begin{array}{c}\text { Kebiasaa } \\
\mathrm{n} \\
\text { Membaca }\end{array}$ & $\begin{array}{c}\text { Penguasaan } \\
\text { Kosakata }\end{array}$ & $\begin{array}{c}\text { Kemampuan } \\
\text { Membaca Teks } \\
\text { Prosedur Bahasa } \\
\text { Inggris }\end{array}$ \\
\hline \multicolumn{2}{|l|}{$\mathrm{N}$} & 90 & 90 & 90 \\
\hline \multirow[t]{2}{*}{ Normal Parameters ${ }^{\mathrm{a}, \mathrm{b}}$} & Mean & 18,61 & 16,88 & 22,00 \\
\hline & $\begin{array}{l}\text { Std. } \\
\text { Deviation }\end{array}$ & 4,085 & 3,489 & 5,647 \\
\hline Most Extreme & Absolute &, 089 &, 126 &, 137 \\
\hline \multirow[t]{2}{*}{ Differences } & Positive &, 089 &, 065 &, 137 \\
\hline & Negative &,- 085 &,- 126 &,- 074 \\
\hline \multirow{2}{*}{\multicolumn{2}{|c|}{$\begin{array}{l}\text { Kolmogorov-Smirnov Z } \\
\text { Asymp. Sig. (2-tailed) }\end{array}$}} &, 846 & 1,197 & 1,299 \\
\hline & &, 472 &, 114 &, 068 \\
\hline
\end{tabular}

Dari tabel di atas menunjukkan bahwa uji hipotesis yang menyatakan distribusi data pada analisis regresi ini mengikuti distribusi normal. Hal ini ditunjukkan dengan semua nilai Asymp. Sig > 0,05. Hal ini berarti semua data berdistribusi normal.

b. Uji Multikolinearitas

Uji multikolinieritas bertujuan untuk menguji apakah model regresi ditemukan adanya korelasi yang sempurna antar variabel bebas (independent). Model regresi yang baik seharusnya tidak terjadi korelasi yang sempurna diantara variabel bebas. Salah satu cara untuk untuk mendeteksi adanya multikolinieritas adalah dengan melihat tolerance atau Varian Inflation Factor (VIF). Jika tolerance lebih kecil dari 0,1 atau nilai VIF diatas 10 maka terjadi multikolinearitas. Aturan yang berikutnya adalah jika nilai Tol dan VIF mendekati angka 1 maka dalam analisis regresi ganda tidak ada multikolinearitas. 
INFERENCE: Journal of English Language Teaching

Vol. 3, No. 1, April - July 2020

p-ISSN: 2615-8671

e-ISSN: 2615-868X

Tabel 6.Uji Multikolinearitas

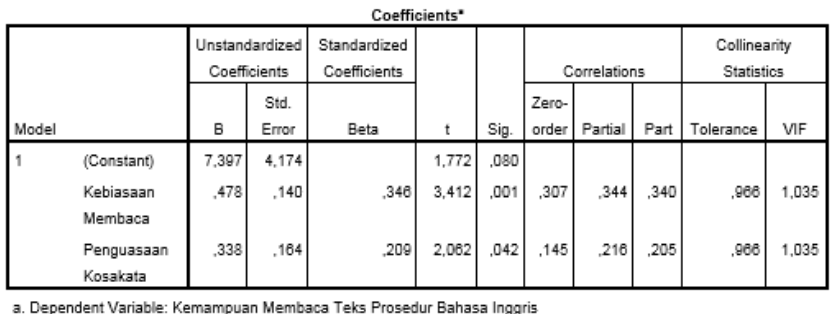

Hasil uji multikolininearitas pada tabel di atas diketahui bahwa hasil Tolerance 0, $966>0,1$ atau varian inflation factor (VIF) $1,035<10$. Sehingga dapat dinyatakan bahwa tidak ada multikolinearitas antara kebiasaan membaca dan penguasaan kosakata pada analisis regresi ganda ini. c. Uji Heteroskedastisitas

Heteroskedastisitas adalah apabila kesalahan atau residual yang diamati tidak memiliki varian yang konstan. Kondisi heteroskedastisitas sering terjadi pada data cross section, atau data yang diambil dari beberapa responden pada suatu waktu tertentu.

Salah satu metode untuk mendeteksi adanya heteroskedastisitas adalah dengan membuat scatter-plot antara Standardized Residual (ZRESID) dan Standardized Predicted Value (Y topi). Pada gambar dibawah ini menunjukkan tidak ada perubahan e sepanjang Y topi, maka dinyatakan tidak ada heteroskedastisitas pada galat (error/residual) tersebut.

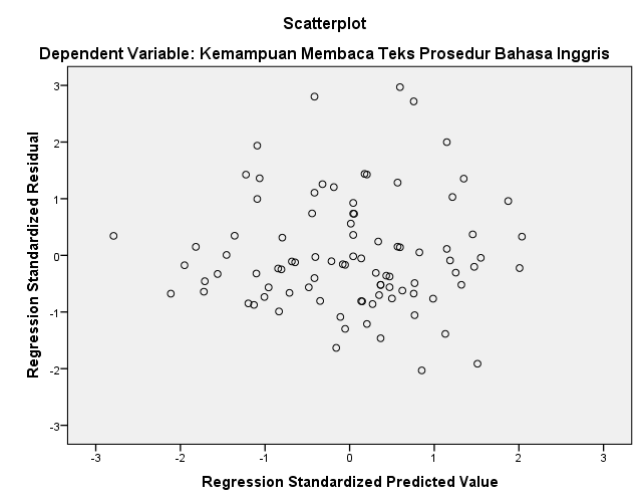

Gambar 5. Scatterplot Uji Heteroskedastisitas

Dari gambar di atas menunjukkan bahwa titik-titik menyebar secara acak dan tidak membentuk pola tertentu yang jelas, serta tersebar di atas maupun di bawah angka 0 pada sumbu Y. Hal ini menunjukkan bahwa tidak terjadi heteroskedastisitas pada model regresi tersebut, sehingga dapat dipakai untuk memprediksi variabel kemampuan membaca teks prosedur bahasa Inggris berdasarkan minat baca dan penguasaan kosakata.

d. Uji Normalitas Galat

Persyaratan regresi yang baik jika data penelitian mengikuti distribusi normal. 
Tabel 6.Uji Normalitas Galat

\begin{tabular}{|c|c|c|}
\hline & & $\begin{array}{c}\text { Unstandardized } \\
\text { Residual }\end{array}$ \\
\hline \multicolumn{2}{|l|}{$\mathrm{N}$} & 90 \\
\hline \multirow[t]{2}{*}{ Normal Parameters ${ }^{a, b}$} & Mean &, 0000000 \\
\hline & $\begin{array}{l}\text { Std. } \\
\text { Deviation }\end{array}$ & 5,24692965 \\
\hline Most Extreme & Absolute &, 119 \\
\hline \multirow[t]{2}{*}{ Differences } & Positive & ,119 \\
\hline & Negative &,- 077 \\
\hline \multirow{2}{*}{\multicolumn{2}{|c|}{$\begin{array}{l}\text { Kolmogorov-Smirnov Z } \\
\text { Asymp. Sig. (2-tailed) }\end{array}$}} & 1,133 \\
\hline & &, 154 \\
\hline
\end{tabular}

Dari tabel di atas menunjukkan bahwa uji hipotesis yang menyatakan distribusi residual pada analisis regresi ini mengikuti distribusi normal. Hal ini ditunjukkan dengan nilai $Z=1,133$ dan Sig. $=0,154>$ 0,05 . Hal ini berarti asumsi atau persyaratan analisis regresi terpenuhi.

e. Uji Linearitas

Uji lineritas dilakukan untuk menentukan teknik dalam analisis regresi apakah variabel bebas $\left(\mathrm{X}_{1}\right.$ dan $\mathrm{X}_{2}$ ) dan variabel terikat $(\mathrm{Y})$ terbentuk linear. Uji linearitas ini menggunakan perhitungan SPSS 22 a. Linieritas Regresi Pengaruh Variable $\mathrm{X}_{1}$ atas $\mathrm{Y}$

Hasil uji linearitas regresi antara kebiasaan membaca dengan kemampuan membaca teks prosedur bahasa Inggris, perhitungan SPSS 22 sebagai berikut:

Tabel 7. Hasil Pengujian Linearitas Regresi Variabel $\mathrm{Y}$ atas $\mathrm{X}_{1}$

\begin{tabular}{|c|c|c|c|c|c|c|c|}
\hline & & & $\begin{array}{c}\text { Sum of } \\
\text { Squares }\end{array}$ & $\mathrm{df}$ & $\begin{array}{c}\text { Mean } \\
\text { Square }\end{array}$ & $\mathrm{F}$ & Sig. \\
\hline \multirow{5}{*}{$\begin{array}{l}\text { Kemampuan Membaca } \\
\text { Teks Prosedur Bahasa } \\
\text { Inggris * Kebiasaan } \\
\text { Membaca }\end{array}$} & \multirow[t]{3}{*}{ Between Groups } & $\begin{array}{l}\text { (Combined } \\
\text { ) }\end{array}$ & 741,247 & 18 & 41,180 & 1,394 &, 162 \\
\hline & & Linearity & 268,052 & 1 & 268,052 & 9,077 &, 004 \\
\hline & & $\begin{array}{l}\text { Deviation } \\
\text { from } \\
\text { Linearity } \\
\end{array}$ & 473,196 & 17 & 27,835 & 943 & .530 \\
\hline & \multicolumn{2}{|l|}{ Within Groups } & 2096,753 & 71 & 29,532 & & \\
\hline & \multicolumn{2}{|l|}{ Total } & 2838,000 & 89 & & & \\
\hline
\end{tabular}

Berdasarkan hasil perhitungan di atas diperoleh hasil perhitungan Deviation from Linearity dengan Fo $=0,943$ dan Sig. $=0,530>0,05$. Hal ini memiliki pengertian bahwa variabel kebiasaan membaca dengan kemampuan membaca teks prosedur bahasa Inggris siswa mempunyai mempunyai hubungan yang tidak linear.

b. Linieritas Regresi Pengaruh Variabel $\mathrm{X}_{2}$ atas $\mathrm{Y}$

Hasil uji linearitas regresi antara penguasaan kosakata dengan kemampuan membaca teks prosedur bahasa Inggris dengan perhitungan SPSS 22 sebagai berikut:

Tabel 8.Hasil Pengujian Linearitas Regresi Variabel $\mathrm{Y}$ atas $\mathrm{X}_{2}$

\begin{tabular}{|c|c|c|c|c|c|c|c|}
\hline & & & $\begin{array}{l}\text { Sum of } \\
\text { Squares }\end{array}$ & $d f$ & $\begin{array}{c}\text { Mean } \\
\text { Square }\end{array}$ & F & Sig. \\
\hline \multirow{5}{*}{$\begin{array}{l}\text { Kemampuan Membaca Teks } \\
\text { Prosedur Bahasa Inggris * } \\
\text { Penguasaan Kosakata }\end{array}$} & Between Groups & $\begin{array}{l}\text { (Combine } \\
\text { d) }\end{array}$ & 395,675 & 15 & 26,378 &, 799 & $\begin{array}{r}, 67 \\
5\end{array}$ \\
\hline & & Linearity & 60,005 & 1 & 60,005 & 1,818 &, 18 \\
\hline & & $\begin{array}{l}\text { Deviation } \\
\text { from } \\
\text { Linearity }\end{array}$ & 335,670 & 14 & 23,976 &, 726 & $\begin{array}{r}, 74 \\
1\end{array}$ \\
\hline & Within Groups & & 2442,32 & 74 & 33,004 & & \\
\hline & Total & & $\begin{array}{r}2838,00 \\
0\end{array}$ & 89 & & & \\
\hline
\end{tabular}


INFERENCE: Journal of English Language Teaching

Vol. 3, No. 1, April - July 2020

p-ISSN: 2615-8671

e-ISSN: 2615-868X

Berdasarkan hasil perhitungan di atas diperoleh hasil Deviation from Linearity dengan Fo $=0,726$ dan Sig. $=0,741<0,05$. Hal ini memiliki pengertian bahwa variabel penguasaan kosakata dengan kemampuan membaca teks prosedur bahasa Inggris siswa mempunyai hubungan yang linear.

\section{B. Pengujian Hipotesis}

Pengajuan hipotesis dilakukan sesuai dengan ketentuan yang telah dijelaskan dalam metode. Hasil perhitungan dan pengujian bisa dilihat pada tabel di bawah ini:

Tabel 9.Hasil Perhitungan Pengujian Koefisien Korelasi Ganda Variabel $\mathrm{X}_{1}$ dan $\mathrm{X}_{2}$ terhadap $\mathrm{Y}$

Model Summary

\begin{tabular}{|l|c|r|r|r|}
\hline Model & R & R Square & $\begin{array}{c}\text { Adjusted R } \\
\text { Square }\end{array}$ & $\begin{array}{c}\text { Std. Error of } \\
\text { the Estimate }\end{array}$ \\
\hline 1 &, $370^{\mathrm{a}}$ &, 137 &, 117 & 5,307 \\
\hline
\end{tabular}

a. Predictors: (Constant), Penguasaan Kosakata, Kebiasaan membaca

Tabel 10.Hasil Perhitungan Pengujian Signifikansi Koefisien Regresi Variabel $\mathrm{X}_{1}$ dan $\mathrm{X}_{2}$ terhadap Y

\begin{tabular}{|ll|r|r|r|r|r|}
\hline \multicolumn{1}{|l|}{} & & \multicolumn{1}{|c|}{ Sum of } & & Mean & & \\
Model & & Squares & df & Square & F & Sig. \\
\hline 1 & Regression & 387,806 & 2 & 193,903 & 6,885 &, $002^{\mathrm{b}}$ \\
& Residual & 2450,194 & 87 & 28,163 & & \\
& Total & 2838,000 & 89 & & & \\
\hline
\end{tabular}

a. Dependent Variable: Kemampuan Membaca Teks Prosedur Bahasa Inggris

b. Predictors: (Constant), Penguasaan Kosakata, Kebiasaan Membaca

\begin{tabular}{|c|c|c|c|c|c|c|}
\hline \multicolumn{7}{|c|}{ Coefficients $^{\mathrm{a}}$} \\
\hline \multirow{2}{*}{\multicolumn{2}{|c|}{ Model }} & \multicolumn{2}{|c|}{$\begin{array}{l}\text { Unstandardize } \\
\text { d Coefficients }\end{array}$} & \multirow{2}{*}{$\begin{array}{c}\text { Standardize } \\
\mathrm{d} \\
\text { Coefficient } \\
\mathrm{s} \\
\\
\text { Beta } \\
\end{array}$} & \multirow[b]{2}{*}{$\mathrm{t}$} & \multirow[b]{2}{*}{ Sig. } \\
\hline & & $\mathrm{B}$ & $\begin{array}{c}\text { Std. } \\
\text { Error }\end{array}$ & & & \\
\hline & (Constant) & $\begin{array}{r}7,39 \\
7\end{array}$ & 4,174 & & 1,772 &, 080 \\
\hline & Kebiasaan Membaca &, 478 &, 140 & 346 & 3,412 &, 001 \\
\hline & Penguasaan Kosakata &, 338 &, 164 & ,209 & 2,062 &, 042 \\
\hline
\end{tabular}

1. Pengaruh kebiasaan membaca $\left(X_{1}\right)$ dan penguasaan kosakata $\left(X_{2}\right)$ secara bersama-sama terhadap kemampuan membaca teks prosedur bahasa Inggris $(\mathrm{Y})$

Hipotesis yang diuji:

Artinya:

$$
\begin{aligned}
& H_{0}: \beta_{y 1}=\beta_{y 2}=0 \\
& H_{1}: \beta_{y 1} \neq 0, \text { atau } \beta_{y 2} \neq 0
\end{aligned}
$$

$\mathrm{H}_{0} \quad$ : $\quad$ Tidak terdapat pengaruh kebiasaan membaca dan penguasaan kosakata secara bersama-sama terhadap kemampuan membaca teks prosedur bahasa Inggris

$\mathrm{H}_{1} \quad$ : $\quad$ Terdapat pengaruh kebiasaan membaca dan penguasaan kosakata secara bersama-sama terhadap kemampuan membaca teks prosedur bahasa Inggris.

2. Pengaruh minat baca $\left(\mathrm{X}_{1}\right)$ terhadap kemampuan membaca teks prosedur bahasa Inggris $(\mathrm{Y})$

Hipotesis yang diuji:

$$
\begin{aligned}
& H_{0}: \beta_{y 1}=0 \\
& H_{1}: \beta_{y 1} \neq 0
\end{aligned}
$$


Artinya:

$\mathrm{H}_{0} \quad$ : $\quad$ Tidak terdapat pengaruh kebiasaan membaca terhadap kemampuan membaca teks prosedur bahasa Inggris

$\mathrm{H}_{1} \quad$ : $\quad$ Terdapat pengaruh kebiasaan membaca terhadap kemampuan membaca teks prosedur bahasa Inggris.

3. Pengaruh penguasaan kosakata $\left(\mathrm{X}_{2}\right)$ terhadap kemampuan membaca teks prosedur bahasa Inggris $(\mathrm{Y})$ Hipotesis yang diuji:

$$
\begin{aligned}
& H_{0}: \beta_{y 2}=0 \\
& H_{1}: \beta_{y 2} \neq 0
\end{aligned}
$$

Artinya:

$\mathrm{H}_{0} \quad$ : $\quad$ Tidak terdapat pengaruh penguasaan kosakata terhadap kemampuan membaca teks prosedur bahasa Inggris

$\mathrm{H}_{1} \quad$ : $\quad$ Terdapat pengaruh penguasaan kosakata terhadap kemampuan membaca teks prosedur bahasa Inggris.

\section{Simpulan}

Terdapat pengaruh yang signifikan kebiasaan membaca dan penguasaan kosakata secara bersamasama terhadap kemampuan membaca teks prosedur bahasa Inggris siswa SMP Swasta di Jakarta Timur. Hal ini dibuktikan dengan perolehan nilai Sig $=0,000<0,05$ dan $\mathbf{F}_{\text {hitung }}=6,885$. Terdapat pengaruh yang signifikan kebiasaan membaca terhadap kemampuan membaca teks prosedur bahasa Inggris siswa SMP Swasta di Jakarta Timur. Hal ini dibuktikan dengan perolehan nilai Sig $=0,001<$ 0,05 dan $t_{\text {hitung }}=3,412$. Terdapat pengaruh yang signifikan penguasaan kosakata terhadap kemampuan membaca teks prosedur bahasa Inggris siswa SMP Swasta di Jakarta Timur. Hal ini dapat dibuktikan dengan perolehan nilai Sig $=0,042<0,05$ dan $t_{\text {hitung }}=2,062$.

\section{Daftar Rujukan}

Chettri, K. \& Rout, S.K. (2013). Reading Habits: An overview. Journal of Humanities and Social Science. (I05R-JH55) (14) 6. pp 13-17

Fletcher, P. (2005). Developmental Theory and Language Disorders. London: Publishing Company. Gardner, B. (2012). An article: Habit as Automaticity, not Frequency. London: University College London.

Harmer, J. (2002). The Practice of English Language Teaching. Longman 